\title{
Vybrané okolnosti Helfertových interpretačních a organizačních aktivit
}

\section{Selected Circumstances of Helfert's Performing and Organizational Activities}

Jan Špaček / spacek@phil.muni.cz

Ústav hudební vědy FF MU, Brno, CZ

\begin{abstract}
The study describes selected circumstances of Helfert's activities as conductor of the Orchestral Association in Brno that he presided and conducted from the beginning of 1920s and of the Collegium Musicum at the Masaryk University that he founded, organized and conducted from 1928. With the latter he conducted concerts broadcast live by the Czech Radio "Radio-Journal" on a regular basis, mostly of early Czech classical-style music. Some literature brings information about a series of four concerts of contemporary Soviet music taking place in 1934. However, there is no mention of these in available sources. Helfert, although uncompromising as a critic, was also an enthusiastic defender of amateur music activities. The Institute of Musicology at the Masaryk University maintains this tradition until present.
\end{abstract}

\section{Key words}

Vladimír Helfert, Gracian Černušák, Orchestral Association, Collegium musicum, Radio-Journal 
Ve svém textu se věnuji nejen vybraným jednotlivým okolnostem Helfertových organizačních a interpretačních aktivit, ale především duchu Helfertova přístupu k hudbě jako takové, v němž neexistuje rozpor mezi profesionální povahou muzikologické práce a amatérskou úrovní hudební interpretace, protože ochotnická hudební aktivita libovolné pokročilosti je u něj chápána jako přirozený projev lidské kulturní identity.

Vycházím z dostupných spisů týkajících se Helfertovy činnosti, především z Pečmanovy monografie vydané roku 2003, dále z jeho článku Naše Collegium musicum, vydaného v roce 2007 v revue Universitas, a z bakalářské diplomové práce Kateřiny Kubíkové, nyní Valové, obhájené na Ústavu hudební vědy FF MU v červnu 2012, s názvem Orchestrálni sdruženi v Brně v době pưsobeni Vladimíra Helferta (1920-1939). Vedla ji, myslím, velmi úspěšně, Veronika Vejvodová. Využívám také pramenů k činnosti Orchestrálního sdružení v Brně dostupných v Oddělení dějin hudby Moravského zemského muzea, konkrétně zápisů ze schůzí a z kroniky.

O Helfertových interpretačních zkušenostech z dětství se zatím nedaří najít nic konkrétního a kupříkladu Rudolf Pečman uvádí ve své monografii jako první informaci, že během svých pražských studií prohlubuje Helfert své pianistické umění i znalost hudební teorie u Fibichova žáka Bohumila Vendlera. Sám Helfert ve svém dojemném testamentu Moje literárni plány (Pečman 2003, str. 179-183), psaném v lednu 1942 v nemocnici ve slezské Olavě (Wohlau), vzpomíná, jak mu maminka v jeho 14 letech nedovolila jít na konzervatoř a stát se dirigentem, což prý nakonec bylo správné rozhodnutí, neukojilo však jeho touhu po dirigování - k tomu nakonec došlo až v lednu 1921, kdy se u dirigentského pultu brněnského Orchestrálního sdružení Helfert objevuje poprvé.

Činnost Orchestrálního sdružení v Brně je v dostupné literatuře podrobně zmapována a archivní prameny týkající se činnosti sdružení jsou k dispozici v Oddělení dějin hudby MZM: Poprvé Sdruženi vystoupilo v roce 1906, Helfert je umělecky vedl od svého jmenování koncem roku 1920 až do svého prvního zatčení Gestapem v listopadu 1939 a Helfertovo jméno přidalo do svého názvu v červnu 1945, tedy měsíc po jeho smrti. Z charakteristických rysů Helfertovy práce ve sdružení vybírám jen některé: Základem repertoáru byla Smetanova Má vlast a Dvořákovy Slovanské tance. Jak dokládá Kubíková-Valová, byl Helfert spolu se Sdružením zakladatelem smetanovské tradice či přímo smetanovského kultu na Moravě, kde do té doby dominovala hudba období klasicismu. Nabízí se otázka: dožije se kdokoliv z nás kompletního provedení Mé vlasti ve Vyškově, v Blansku, v Třebíči či v Náměšti nad Oslavou, tak jako to bylo obvyklé v době Helfertových „diletantů“?

Repertoár krom jmenovaných dvou stálic sestával z hudby českého i světového klasicismu, v menší míře pak z hudby novější. Největší zaznamenané obsazení mělo v letech 1927-1931: 109 hráčů. Kromě Mé vlasti patřily k nejexponovanějším skladbám co do počtu hráčů Lisztova Preludia (Les Préludes), Mahlerova první či Sibeliova druhá symfonie, Dvořákův Vodník a symfonická díla Vítězslava Nováka. Naopak z předklasické hudby to byl takřka výhradně Bach, jen v jediném případě Corelli. Ve sdružení Helfert zdaleka nedirigoval všechny koncerty, naopak zval ke spolupráci významné osobnosti, především svưj dirigentský vzor Ludvíka Vítězslava Čelanského, i v těchto případech však skladby s orchestrem studoval Helfert a hosty zval až na poslední zkoušky před koncertem, jednu až tři. 
Druhou Helfertovou významnou interpretační aktivitou bylo univerzitní Collegium musicum, jež založil v roce 1928 po vzoru německých univerzit. Zde se ovšem potýkáme s nesrovnatelně horší dostupností pramenů a minimální reflexí v odborné literatuře. $\mathrm{V}$ revue Masarykovy univerzity Universitas vyšla v roce $2007 \mathrm{v}$ rubrice $Z$ historie a současnosti univerzity studie Rudolfa Pečmana Naše Collegium musicum. Neuvádí však prameny ani literaturu a není jasné, odkud čerpá. Přináší přitom některé zajímavé skutečnosti, např́klad že: „Roku 1934 prípravilo Collegium musicum zásluhou Václava Kaprála, jenž byl mj. lektorem hudebni teorie při seminári hudebni vědy, cyklus čtyř večerĩ z tehdejších dèl sovětských skladatelu․ Kaprál prìvezl hudebni materiály z cesty po SSSR, večery se konaly v aule FF a byly přimo vysilány rozhlasem nejen $k$ našim rozhlasovým prédplatiteliom, nýbrž př́mo $i$ do Sovètského svazu. "Jedná se tu o jistý posun oproti helfertovské monografii, jež vyšla o čtyři roky dříve. Ve stejné věci je v ní (str. 129) Kaprál zmiňován jen jako ten, kdo partitury přivezl, zatímco interpretace i dramaturgie je připsána Helfertovi. O Collegiu se v ní ještě nemluví, sovětský cyklus je naopak zmíněn v souvislosti s činností Orchestrálního

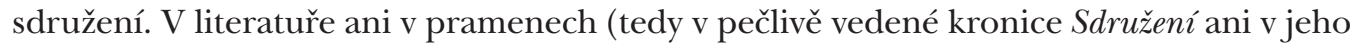
jubilejních sbornících) není o sovětském koncertním cyklu ani zmínka.

Bližší informace o skladbách prováděných v tomto cyklu či o interpretačním obsazení tedy v tuto chvíli nemáme a nezmiňuje se o nich ani časopis Radio-Journal z roku 1934. Tento podrobný týdeník přináší program všech československých i evropských rozhlasových stanic a o výjimečných projektech typu př́mých přenosů vždy informoval ještě $\mathrm{v}$ samostatných článcích. $\mathrm{V}$ několika případech se jedná o přímé přenosy z Helfertových fakultních koncertů s Collegiem musicum, vždy šlo ale o skladby českého klasicismu a nic ani vzdáleně nepřipomínalo hudbu soudobou, neřku-li sovětskou. Byl by to ojedinělý příklad Helfertova skutečného interpretačního zaujetí zahraniční soudobou hudbou, a to dokonce ve čtyřech koncertech živě přenášených rozhlasem.

Úspěch nepřineslo ani pátrání $\mathrm{v}$ archivu MU, který nepoužívá katalogy a dokumenty vyhledává výhradně na základě konzultací a následných rešerší prováděných pracovníky archivu. Dr. Jiřina Kalendovská v odpovědi ze začátku listopadu 2015 sděluje, že prošla materiály uložené v Archivu MU (fond A 2 Filozofická fakulta MU, sign D X Hudebně-historický seminář), a to od r. 1928, kdy bylo Collegium založeno (Pečman 2007). „Kromě vyúčtováni 500 Kč za hudebni kolegium v Radiožurnálu v r. 1933 (A 2 FF MU, D $X, \check{c} . j . \quad 1586 / 1933, k .35)$ jsme dalš́ materiály nenašli. Prof. Pečman na konci zmiňovaného př́spěvku piše: Literatura je $k$ dispozici u autora. Jeho osobni fond, ve kterém by mohly být $i$ materiály sdruženi Collegium musicum, u nás bohužel uložen neni."

Je pravdou, že zmíněný Pečmanův článek v revui Universitas namísto výběrového výčtu nejdůležitějších pramenů, případně literatury, skutečně zakončuje tajemně pưsobící upozornění, že „Literatura je $k$ dispozici u autora“. Samotný text také mnoho indicií nedává, nicméně některé údaje ryze věcné či statistické povahy se v textu objeví: kromě výběrového výčtu jmen členů Collegia také datum jeho založení (27. listopad 1928) a údaj, že Helfert s Collegiem připravil pro rozhlas „asi 20 relaci“. Jde tedy o výsledek pramenného výzkumu, ovšem jeho vesměs spíse přibližný charakter nenapovídá na prostý sběr informací (např. z rozhlasového časopisu Radio-Journal), nýbrž spíše na náhodný a nekonzistentní soubor jednotlivých pramenů. Pečman zřejmě bud'to vycházel z vlastních starších 
rešerší, jejichž původ již nebylo možné přesně formulovat do podoby bibliografie, nebo měl skutečně $\mathrm{k}$ dispozici dokumenty $\mathrm{k}$ počátkům činnosti Collegia musicum brněnské univerzity a ty se po jeho smrti v prosinci 2008 zřejmě - snad - dostaly mezi dosud nezpracované materiály z jeho pozůstalosti, uložené v Oddělení dějin hudby MZM. V každém případě lze s jistotou tvrdit, že se tu v menší či větší míre jedná o omyl, a vyloučíme-li nepravděpodobné okolnosti jako např. náhlou neanoncovanou změnu programu, nedošlo v roce 1934 v Brně k žádnému rozhlasovému přenosu se sovětskou hudbou.

Rád bych také krátce věnoval pozornost kritické reflexi Helfertova působení v čele Orchestrálního sdružení, a to za základě četných výstřižků z kroniky. V prvních letech činnosti sdružení tyto texty, ačkoliv povahy důsledně kritické, Helfertovo umění bezvýhradně chválí a vyzdvihují jeho přesné a věcné gesto, což, mimochodem, poněkud kontrastuje s ohleduplně formulovanými náznaky v publikovaných vzpomínkových textech členů Sdružení, které zmiňují převahu vášnivosti Helfertova dirigentského projevu nad přesností gesta. Vyzdvihuje se kvalitativní růst koncert od koncertu. Ještě v roce 1923 převažuje chvála i nadšení, ale počet kritických postřehů roste, především na výkonnostní nevyrovnanost jednotlivých členů, ale i na špatnou nástrojovou výbavu např. u bicích či dřev.

K jistému zlomu dochází po ryze dvořákovském koncertě 4. prosince 1923, na němž zazněla Husitská, Polednice, Vodník a Symfonie č. 9. Koncert ř́́dil Čelanský. Stráž lidu, Rovnost i Moravské noviny přinesly dosti příznivé recenze, do Lidových novin (vše výstřrižky z Kroniky OS) ovšem Gracian Černušák (pod zkratkou „-k“) napsal: „Nechci nijak křivditi Orkestrálnímu sdruženi, jehož krásné vlastnosti byly prece na tomto mistě opětovně uznány, ale zdá se mi, že doba, po kterou se mohlo sdruženi věnovat tomuto pořadu, byla přece jenom poněkud krátká, než aby díla byla opravdově zažita. Veliká dirigentská zručnost Čelanského dovedla sice dát skladbám efektni vnějši proud, jsouc podporována hlubokou oddaností a nadšením členstva, ale po technické stránce byly prirrozené vady ochotnického orkestru velmi patrné, místa intonačně jen poněkud choulostivějš́ nevyzněla čistě a zvuk byl v mistech dynamicky hutnějš́ch hrubý. Nepochybuji, že se dalši praci počet těchto závad podstatně zmenši a že se tak zjedná nutná rovnováha pojeti a technického provedeni." Navzdory opatrným a diplomatickým formulacím vyprovokoval Černušák reakci a v Lidových novinách je otištěno polemické „Zasláno“ od výboru Orchestrálního sdružení, kde se Černušákovi mj. vytýká, že „úmyslně poškozuje a chce zdiskreditovat". Helfert se sice v další výměně nehlásí k autorství textu, vyjadřuje s ním ale jednoznačný souhlas.

V tuto chvíli se spor mezi Černušákem a Helfertem přenáší do neveřejné roviny a ukazuje mnoho o tom, jak nesmlouvavě byli oba ochotni hájit své mínění, samozřejmě při zachování veškerého bontonu. Černušák posílá Helfertovi osobní čtyřstránkový strojopisný dopis, v němž odmítá odpovídat veřejně, odkazuje na svědectví mnoha dalších hudebníků a dovolává se dřívější Helfertovy podpory v Černušákových sporech s umělci, mj. i slovy: „Dnes jsou tedy jiné poměry a řeknu Vám, že by mi bylo préece jenom bolestno loučit se s obrazem, jaký o Vás mám. "Zdůrazňuje, že nedostatek zkoušek byl tím nejšetrnějším, čím mohl své postřehy zdůvodnit, a že volil veskrze vstřícný tón, za což nezasluhuje pokus o diskreditaci. $\mathrm{K}$ výkonu sdružení mj. podotýká: „Byl jste prece př́tomen koncertu a třebas vím, že láska umí prédev̌š́m odpouštět, nemohl jste neslyšeti na př. nesmírné nečistoty ve všech 
př́padech, kde různé nástroje, např. housle a violoncella ap., vystupovaly jen poněkud exponovaně v unisonu nebo v oktávách, nemohl jste přece neslyšeti onoho strašného závěrečného akordu $v$ druhé větě symfonie atd."

Rukopisný koncept Helfertovy odpovědi plný škrtů a oprav se rovněž dochoval a nutno říct, že Helfert s Černušákem nesouhlasí takřka v ničem, jen v tom jednom „zkaženém“ akordu, vše ostatní větu po větě důsledně popírá. Překvapivě působí Helfertovo zjevné emoční rozrušení, jež se projevuje nejen vnějškově (škrty a rozsahem dopisu - šest stran formátu A4), ale i argumentací: mohlo to jít „na vrub okamžité nervózy orchestru“, ale zároveň byl Vodník až na jediné místo a jediný nástroj bezvadný a, v dodatečném vpisu: „Nejuětši část Polednice a Husitské taktéž." Proti kritickému soudu Černušákovu staví nezištnost činnosti všech členů Sdružení. Příkře Helfert odmítá i soudy Černušákových kolegů z konzervatoře: jsou prý egoističtí a duševně omezení: „kolik už z těch patentovaných muzikantů usilovalo vetřiti se do našeho Sdruženi, když viděli, že naše Sdruženi roste! Chtěli tak jen proto, aby se mohli ,uplatnit‘. Mám své míněni o těch pánech: prodají svou duši za čočovici. “

Je zjevné, že se Vladimír Helfert cítil být poškozen hudebními profesionály reprezentovanými lidmi z konzervatoře, kteří sledují jen technická kritéria a nedokážou ocenit amatérský interpretační zápal, a chová k nim jen minimální respekt. Není důležité a vlastně ani možné hledat pravdu na straně jednoho či druhého. Důležité je, že si byl Helfert plně vědom nejen správnosti svého amatérského počínání, ale i potřeby bránit je před zjednodušujícím pohledem profesionálů, jakkoliv může být jeho reakce hodnocena ublíženě a nepřiměřeně.

Nebyl to však Helfertův první spor o kritiku. Svatava Přibáňová (V. H. v českém a evropském kontextu, 1987) se ve své studii Vl. Helfert a Gr. Černušák věnuje především plodné, i když nezřídka komplikované spolupráci obou osobností na velkolepém brněnském slovníkovém projektu, upozorňuje ovšem také na okolnosti Helfertova odchodu z Prahy a na soudní spor, který s Helfertem v roce 1915 vedl pěvec Jiří Huml. Nikoliv jako kritik, nýbrž jako učitel odpovědný za studentská představení obvinil jednou po odpolední Prodané nevěstě Helfert Humla, že záměrně odbyl roli Kecala, ten však s odkazem na zdravotní indispozici soudní při „komických rozměrü“ po dlouhých průtazích vyhrál a Helfert musel zaplatit pokutu i soudní výlohy. Podle Přibáňové tato nepříjemnost spolu se zjištěním, že Nejedlého vědeckou hegemonii v Praze nelze nikterak narušit, nejvíce přispěla $\mathrm{k}$ jeho rozhodnutí přesídlit do Brna.

Závěrem: Helfert nejenže položil pevný základ celé řadě badatelských zaměření, jež jsou tímto ústavem rozvíjeny dodnes, nejenže založil dodnes živou tradici přátelské a laskavé atmosféry mezi učiteli a studenty, ale ukázal také obrovské možnosti a úctyhodné výsledky amatérské hudební aktivity v podání studentů a absolventů brněnské muzikologie i členů širší akademické obce, jak se patří u collegia musicum s celouniverzitním záběrem. Na tuto tradici se v posledních letech daří opět navázat, ovšemže v nových podmínkách a v kontextu odlišných interpretačních výzev. Díky aktivitě zdejších studentů a pedagogů vznikl kupříkladu elitní komorní vokální soubor Ensemble versus, který se specializuje na duchovní tvorbu předklasickou a postromantickou a navázal trvalou spolupráci s mladým poloprofesionálním orchestrem Ensemble Opera Diversa, dále Symfonický orchestr Masarykovy univerzity, který je dnes již schopen provádět 
standardní romantický repertoár (Dvořák, Čajkovskij, Verdi) a přebírá tak štafetu po tradičních brněnských amatérských orchestrech, konkrétně po dnes již bohužel prakticky neaktivním Helfertově orchestrálním sdružení a po definitivně již zaniklém Symfonickém orchestru železničářů. Třicetičlenný mužský pěvecký sbor Láska opravdivá oživuje postupně zanikající tradici mužských pěveckých spolků a udržuje tak při životě unikátní repertoár druhé poloviny 19. a začátku 20. století, především Leoše Janáčka, a kupř́íkladu 1. března 2015, troufám si říci, že v naprostém souladu s hudebními preferencemi Vladimíra Helferta, souborně provedl a capella mužské sbory Bedřicha Smetany v Praze ve dvoraně Českého muzea hudby. Velký smíšený sbor Collegia musicum sdružuje každý semestr na 120 zpěváků z řad zájemců všech pokročilostí z celé univerzity, vystupuje pod názvem Akademický smíšený pěvecký sbor Pečman, nejčastěji s díly Janáčkovými, Smetanovými a Rachmaninovovými a v současnosti připravuje souborné provedení a capella smíšených sborů Antonína Dvořáka. V současnosti na půdě ústavu klíčí samostatné studentské iniciativy zaměřené na interpretaci instrumentální hudby druhé poloviny 20. století, na tzv. gospelovou hudbu a také barbershop quartet.

Domnívám se, že standardní profesionální hudební infrastruktura filharmonií a spolků přátel hudby, zahrnujících orchestry, pěvecké sbory i komorní soubory, jež se v evropských metropolích a poté i v menších sídlech postupně vyvinula, vykrystalizovala z touhy desítek tisíc hudebních amatérů po vysokém a neprofesionálními hudebníky těžko dosažitelném interpretačním projevu. Přibližně od poloviny 20. století zažívá tato infrastruktura svoji institucionální konjunkturu, paralelně s tím ovšem postupně ochabují hudební aktivity amatérské, někde vinou totalitních režimů rychleji, jinde pozvolna. Bude otázkou, jak se v budoucnu promění činnost a především úroveň profesionálních těles bez soustavného tlaku hudbyznalých nadšených amatérů, jejichž nejúspěšnějším reprezentantem byl právě Vladimír Helfert, který však představoval jen špičku ledovce. Pokles nabídky amatérských hudebních aktivit vede ke snižování hudební gramotnosti publika a tedy i k jeho sníženým nárokům na kvalitu profesionálního projevu. Bez helfertovské „umělecké vášně“ ztrácí profesionální interpretační umění svoji hlavní motivační oporu a zažívá dříve nemyslitelné výkonnostní výpadky.

N. B. Na přání prof. Jiřího Vysloužila vyslovené v diskusi po přednesení tohoto příspěvku připojuji do textu ústně předávanou anekdotu o vystoupení Orchestrálního sdružení kdesi u Vyškova na hrázi rybníka. Pódium tam prý bylo postaveno ledabyle a část hudebníků při vystoupení k velkému pobavení publika popadala do vody. Tento přípis budiž světlou vzpomínkou na vždy pohotového diskutéra Vysloužila, který 26. listopadu 2015, osm dní po helfertovské konferenci, náhle umírá. 


\section{Bibliography}

Kronika Orchestrálního sdružení v Brně 1903-1976, Moravské zemské muzeum, Oddělení dějin hudby, sign. G 6.267.

Zápisy ze schůzí Orchestrálního sdružení v Brně 1921-1964, Moravské zemské muzeum, Oddělení dějin hudby, sign. G 6.268 .

Radio-Journal: věstník čsl. zpravodajské a radiotelefonické spol. s r. o. „Radiojournalu“ v Praze. Praha: Orbis, roč. 12, 1934.

KUBÍKOVÁ, Kateřina (vd. Valová). Orchestrálni sdruženi v Brně v době puisobeni Vladimíra Helferta (1920-1939): bakalářská diplomová práce ÚHV FF MU. Brno: 2012, dostupná online (pdf): http://is.muni.cz/th/361629/ff_b/Bakalarska_diplomova_prace.pdf

PEČMAN, Rudolf. Vladimír Helfert. 1. vyd. Brno: Nadace Universitas Masarykiana Brno, Akademické nakladatelství CERM a Nakladatelství NAUMA, 2003. 232 s. Edice Osobnosti, sv. 20.

PEČMAN, Rudolf. Naše Collegium musicum. Universitas: revue Masarykovy univerzity, 2007, roč. 40, č. 1, s. 19-23, dostupný online (pdf): https://journals.muni.cz/universitas/article/down$\operatorname{load} / 2127 / 1729$

PŘIBÁŇOVÁ, Svatava. Vladimír Helfert a Gracian Černušák. In Vladimír Helfert v českém a evropském kontextu. Rudolf Pečman (ed.). Brno: Svaz českých skladatelů a koncertních umělců, 1987, s. 81-83.

ŠTÁBLOVÁ, Marie (vd. Domská). 100 let Helfertova orchestrálního sdruženi: diplomová práce KHV PdF MU. Brno: 2007, dostupná online (pdf): http://is.muni.cz/th/80520/pedf_m/diplomka.pdf 
